Journal of the Textile Institute Proceedings and Abstracts

\title{
YORKSHIRE SECTION Meeting at Huddersfield, 7th February. 1919. Mr. W. A. Crowther in the Chair: THE ADVANTAGES TO BE DERIVED FROM COMBINATION IN INDUSTRY
}

\section{H. R. Armitage}

To cite this article: H. R. Armitage (1919) YORKSHIRE SECTION Meeting at Huddersfield, 7th February. 1919. Mr. W. A. Crowther in the Chair: THE ADVANTAGES TO BE DERIVED FROM COMBINATION IN INDUSTRY, Journal of the Textile Institute Proceedings and Abstracts, 10:3, 48-54, DOI: $10.1080 / 00405001908630862$

To link to this article: http://dx.doi.org/10.1080/00405001908630862

Published online: 25 Nov 2008.

Submit your article to this journal $₫$

Џ Article views: 2

Q View related articles ¿ 
sides are ontoring into the nogotiations in a friendly spirit. It is a spirit vastly different from that evident elsewhere in the country. But it is not surprising. It is paying no fulsome compliment to the cotton trade to say that it is not only one of the best organised industries in the country, on both sides, but that it almost invariably shows a temper, when labour troubles are under discussion, in which an acrimonious spirit is absent. The Brooklands Agreement, the fame of which still lives, pointed the way not merely to the machinery of adjustment of disputes, but also to the spirit in which to approach differenoes. That spirit survives to-day ; it was apparent at the conference on January 17, and it is not feared that it will be missing at the resumed discussions on March 20. Differences may be keen, but it will be the keenness of business men fighting all out for what they want, and not the keenness of bitter enmity that is irreconcilable. It is this difference, perheps, that stamps the textile industry as a whole sbove others. As the specific matter of hours stands at present, the whole question has gone back to the districts, and it is understood that whilst there will be no attempt to rush it unduly. on the other hand there will be no unnecessery delay. There is a recognition in this latter clause that one way or another the matter will not await settlement. There are not wanting signs in the business world that the revival of trade is not remote, and noither employers nor employed seek to enter a promised boom period with an unsettled dispute on their hands. . - R. C.

THE LATE MR. W. GRIERSON.

The announcement of the death of Mr. W. Grierson, of Bolton, an esteemed member of the Council of this Institute, and an enthusiastic member of the Lanca. shire Section Committee, caused profound regret in many circles. In no organisation was the sense of grief more pronounced among members than in the case of the Textile Institute. The late Mr. Grierson had latterly been ill, and his recovery appeared to be nesring completion. Indeed, after confinement to the house for some time, he had arranged that his first re-appearance on the platform should be as chairman of a Lancashire Section meeting at Bolton on the evening of the 18th February. An internal trouble was diagnosed by his medical advisers, and he was unable to keop tho engagement. An operation was performed, the patient passing away on the following day. Sixty years of age, Mr. Grierson has left a widow, two daughters, and two sons. The late Mr. Grierson entered the cotton trade on lesving the Univereity. He became managing-director of the firm of Messrs. Greenhalgh and Shaw Ltd., Halliwell Mills, Bolton, in 1892. His career has been distinguished for association with great breadth of outlook, and the higher movements, generally, had his keenest sympathy and esrnest support. He was a prominent member of the Manchester Chamber of Commerce for many years, and about a year ago he became president of the Bolton Chamber. A much-travelled man, he was enthusiastically concerned in the whole subject of textile education and instruction, and, latterly, he had engaged in the preparation of a somewhat ambitious scheme of welfare work and education in connection with the employees at the Halliwell Mills. A member of the Council, this Institute has lost a most earnest supporter by the demise of Mr. Grierson. Of late, he had particularly interested himself in helping forward the Foundation Fund of the Institute, and was responsible for securing several donations. The General Secretary of the Institute attended the funeral on Saturday, the 22nd February, at Walmsley Church, near Bolton, and it is a touching circumstance that on the morning of that day a cheque for $£ 250$ wag received at the Institute from the firm of which Mr. Grierson was the head.

\section{PROCEEDINGS OF THE INSTITUTE.}

\section{YORKSHIRE SECTION.}

Meeting at Huddersfield, 7 th February, 1919.

Mr. W. A. Crowthen in the Chair.

\section{THE ADVANTAGES TO BE DERIVED FROM COMBINATION IN INDUSTRY.}

By H. R. Armigage.

AT the outset, I should like to say that no co-operation and no co-ordination in industry can be effective or of any value if individuality is done away with or even impaired. The popular cry against combina. tion is that it does away with individuality. There are kinds of individuality which could be dispensed with to advantage. The better term to employ in this connection would be "individual initiative." What I intend to put before you is an enlarged view of the work of a Committee of the Federation of British Industries, of which I happen to be chairman. The chief points for consideration are set out under different headings :-

Collection and Exchange of Statistical INFormation.-My first object is further to advance a practical suggestion already made by which the follow. ing two important results can be achieved by a Trade Association :-(1) The attainment, by a periodical collection of statistical information, of a scheme of immediate value to members in the conduct of their business; (2) The welding of the association into a more cohesive and therefore more powerful body. The whole tendency of industrialism is in the direction of the massing of interests and the accumulation of forces ; not with the idea merely of gathering numerical strength-which of itself may constitute a positive 
danger-but in order that the changing conditions we see ahead may be directed to the best advantage of those affected by them. This point has been made 80 obvious by the recent trend of industrial and labour movements that there is no need here to lubcur it; it is necessary only to urge that the time is rapidly approaching for us to enquire in which direction the next development may most usefully be made.

Need fou Statistical Gride.-To come to concrete proposals, one of the pressing needs is a more complete statistical guide to immediate conditions and future prospects. The present-day absence of any such guide may be the cause of much worry and anxietv to a mem. ber of the association, and it is hoped here to point out a way in which that worry may be not only relleved but prevented. If a member's trade is down by, say, 25 per cent, he naturally begins to wonder what now move, if any, on the part of his competitors, is telling against him so seriously.

There may be no such move: it may be, morely, that he is suffering in common with the rest of the members, who, on their part, are equally in a stato of anxiety regarding thoir own decreasing output. While it would not entirely remove the distress of mind, it would, at least, be a partitl satisf $\varepsilon$ ction to each of those men to know that in his own case the falling off in trade was not attributable to any leck of zeal or enterprise on his part. This is a matter in which we may well take example from the United States, where a scheme for the collection of statistical trade information has been established in many trades, and is believed to be proving of great utility to those concerned-and this, in spite of the operation of the Sherman Law, which forbids the formation of price rings.

The Scheme Explained.-The first essential of the scheme is to arrive at a basis-an agreed normal -upon which the percentage of capacity would be worked. Whether that basis would be on a pre-war scale or otherwise is a matter for consideration when the details of the scheme are thrsshed out. Having decided unon the normal, it would then become the work of any accountant. by examination of the books of the firms, to arrive at the statistico, rolating to individual firms. which, taken in the buik over the whole of the aseociation, wovld constitute so valuable an indication of the current state of trade. The integrity of the accountant, of course, would be beyond qusition, so that members need have no fear of disclosure of their affairs, contracts, and obligations in a manner harmful to their business. The only figures given to the general body of the members would be a set of percentages which, of course, convey not an atom of information more than is intendeda comparison of any firm's figures, in percentages only, with the. general body of trade.

By this means the individual trader can see almost at a glance whether he is maintaining his position, or whether he is gaining or losing more than, and how much more than, his competitors. Just as the percentage capacity table would shew a member, broadly, the recent progress of his own business as against that of his competitors, so the work ahead table is designed to give him an idea of the probable future conditions of the trade-whether it is keeping up or falling off, or is likely to do either the one or the other.

These, then. are the benefits of the scheme: that a member is afforded a reliable guide as to whether the fluctuations of trade noticeable in his own business are common to the trade as a whrle, and that he is in possession o $i$ useful data for arriving at the conditions under which new erntracts should be mado. The whole design, in short, is to afford to individuals and to the trade as a whole a periodical bird's-eye view of the current position and future pnssililities, the idea being that members are entitled to know more of their general business in bulk than they do now.

If, at the outret, it is felt to be inadvisarle to go the full extent of aupplying particulars in percentage relative to every frm, as is done under similar schemes in America, it would be quite easy to limit the information given to each member oo tho priportion which in any given period his own trade bore to the total volume of business done by the members of the association, together with the percentage increase or decrease of the total volume of the trade. In that case, of course, each individual would be able to compare the fluctuations in his own business with the fluctuations in the general trend of the trade ; but, naturally, he would not be able to form any idea of the extent to which the current of trade had affected his com. petitors individually - whilst, at the same time, the aggregate figures would indicate the position of the whole trade.

EFFECTS on THE Association.-It is submitted that the proposals here made will improve trade relationship without in any way interfering with the individuality of members; and that they will bind trades together in a fashion hardly practicable in any other way. It is not sufficient for the association to increase merely in numbers; such increase, as has already leen pointed out, may be a danger where there is no centralised, co-ordinated policy understood by all and, in its effect, binding upon all. As an organisa. tion-powerful always for its own good-continues to grow, so its members must be watchful against oppression. They must make up their minds that there is a margin of profit beyond which it is not wise to go, either in the general or in the individual interests. They must have in view always the changed and changing relationships with labour; and then, with wise guidance, they may with confidence anticipate a condition of affairs alike advantageous and creditable.

Efficient and Accurate Costing. - Accurate costing is one of the phases of business management to which increased attention will have to be given in this country in the new commercial era following the war. Its importance has not been appreciated to the extent which it deserves, for, while it would be too much to claim that efficiency in costing will save a business from failure, leen attention to costing will undoubtedly go far to ensure success. Every business man, probably, has gone into the question of costings to some extent, but very few have given sufficient consideration to it to get results which are moro 
than a rough guide instead of an absolute check. It may seem a counsel of perfection, but it ought not to be impossible for a firm so to deveiop its costing that, on a monthly comparison of the difference between remaining balance as shown by the ec sting department and the balance as shown by the accounting depart. ment, the margin would not be much more than 5 per cent. The business man of the old type was content. in the main, to rely, if not upon nothing more sustan. tial than instinct, at any rate upon a merely superficia: idea of the weekly or monthly progress of his establish. ment. The business man of the present-and of the future-must have constantly before him exact statis. tical information of the actual position of his concern, alike as regards output. costs, and turnover. Thero is a limit to personal supervision, and with the growth of a successful business moro and more reliance must be placed upon a system of periodical statistical reports from departments as proof of the continued soundness of the management and efficiency of the organisation. Only by such a system can real economy of work be secured-a system that reveals wastefulness in one department, when compared with the results obtained in another, that indicates which lines are and which are not profitable, and, in the case of a Price Associa. tion, that serves to build up its listed prices on a sound basis. In short, uniform and accurate costing then becomes both a guide and a check. For most trades, the post-war resettlement will mean keener competition, and, eventually, narrower margins of profits. There must be closer scrutiny and more frequent and more detailed analysis of working expenses and of costing. and as great a regard for statistical records as for the production processes. Apart from anything else, it is confidently felt that if any trade as a whole knew its real production costs, then even without any arrangement with regard to prices few men would be bold enough or strong enough deliberately to work below that cost. Furthermore, if there is to be limitation of profits-which in many quarters is regarded as an extremely dangerous proposal-it could only be done with the least harm to the trade if an absolutely reliable system of costing had previously been adopted, and the limitation based on average trade costings instead of individual results.

In this development of the costing system, es in so many other spheres of business organisation and onterprise, America has led the way, and it is to that country we may look for useful hints based on sctual experience. In America, we are informed, the best accounting brains are producing a costing system which provides not only for the determination of the amount of each element of cost properly chargeable to each job or oporation, but also for an improved method of bookkeeping which causes the books to reflect at all times the true financial and industrial condition of the business, and renders possible the proparation of monthly statements of conditions as well as complete monthly statements of financial and factory operations. It is the belief of the Federal Trade Commission of the U.S.A. that the small margins of profit existing in so many industries in normal times are due to ignorance on the part of manufacturers of what their goods actually cost to produce. By devoting his attention to oosting, and the establishment of a thoroughly reliable systom, the producer knows definitely the length to which he may go in competition, and he can assess more readily the yield and the value to himself of new types of machinery.

Granted, then, the desirability to the individual trader of the most complete and reliable system of ascertaining the costs of his establishment, what is the collective value of this information? To what extent can it be rendered available for the general good of the trade. It needs to be made quite clear that there is no suggestion of the publication or exchange of figures which are private and vital to the individual members of the industry. The chief object achieved by a voluntary association whose members adopt a systematised method of costing is uniformity. An accountant first of all examines the methods in vogue by the different firms, and, from the experience thus gained, formulates a system calculated to give the most accurate results. This system may be applied to the whole of the members without the privacy of an individual firm being in the least affected. It is not suggested that the figures of any individual business should become known against the will of the proprietor. Yet, without revealing secrets, the experience gained by a uniform and efficient costing system is likely to release a considerable amount of information of general interest and value. Provided it is done mutually, and with the confidence begotten of close business relationship, it is surprising how wide is the range of open conversation nowadays on subjects which, formerly, were as a sealed book. It is beginning to be recognised that secrecy in business can be carried too far ; the old spirit of concealment is disappearing. But the process is slow, and it will be necessary to go in more thoroughly for standardisation of methods before anticipating anything in the nature of interchange of results, either in actual figures or in percentages, and even this later enlargement of the idea can only come about by complete mutuality.

Incidentally, the development of this kind of business organisation, together with the exchange of statistical information, would lead to the introduction of a new type in the profession of accountancy in this country. In America, costing accountancy is a regular profession. The accountant visits a works, and suggests the best type of costing for that works. This is done for a nominal fee and a commission based on the economies effected. Speaking generally, trade in America is a long way ahead of this country in its system of costing and piecework. Here, surely, is a lead which we might follow with advantage. There need be no hesitancy for fear of the revelation of business secrets. The chartered accountant to-day is trusted implicitly ; that trust should not be diminished if he chooses to specialise in one particular trade and bocome the supervisor and collector of statistical data for the members of that trade. If accountants as a body develop this iden it would undeniably enhance the value of the profession and tend to the great benefit of the trades concerned.

Standardisation aND Speoralisation.-Dtudents 
of the science of efficiency in business have laid it down neatly and truthfully that efficiency is to be attained not so much by a greater expenditure of energy as by the elimination of waste.

Efficiency looks for its results to the greatest economy in materisls, in machines, and in men. To that we might add economy in patterns and specifications, and thus eliminate one of the most fruitful sources of waste in the past-the unnecessary multiplication of sorts and types. Here, as elsewhere, the war has brought its particular lesson. The execution of huge orders in the shortest time has only been possible by standardisation of patterns-even down to boots and clothes.

It is clear that standardisation in industry must be divided into two classes - standardisation of machinery, and standardisation of output. So far as the first named is concerned, substantial progress has been made in the engineering industry, while the machine tool makers and the electrical trades have not been slow to realise the advantages of the system. In other directions, however, much remains to be done before we are able to accomplish to the full the large economies possible in the amount of repairs stock it is necessary to carry

We have still to realise the length of the advance made by America and by Germany. We believe that all American electrical machinery is now manufactured to practically the same specifications, so that, in any country in the world, these parts are practically interchangeable. Arrangements are being made to have these standard products described in every language, while the measurements are sent in the measurements of the country concerned. Experience has disproved the eriticism that this system might tend to the discouragement of invention. Instead of aimimg at a change in the whole fabric of a machine, patentees devote themselves more particularly to the improvement of its finer and most essential points, and these are ombodied in a periodical revision of the stendard. Furthermore, specialisation in America has brought about a voluntary interchange of information regarding patents, with the result that litigation on this question is now a thing of the past. The war put an end to a movement for the internstionalisation of standards by which electrical machinery in either Great Britain, Crermany, France, or Italy would all be made to one standard. This international specification, brought about by the British Engineering Standard Association, marks a new era in the objects of voluntary associations, the development of which should be encouraged in other industries where the special conditions of the industry render it advisable.

Coming next to specialisation, we have a long way yot to go before we arrive-even if it were thought desirable to reach it -at the stage of a German firm which specialised so far as to make one type and pattern, and one only, of a cup and saucer, and nothing else.

Both standardisation and specialisation are effects in which financial combinations may get their chief advantages. It is in their case within the power of a few men to decide that instead of using each unit of plant for ten or a hundred different types of production, they will arrange those units in groups, worked on the lines that best fit in with each other. Where financisl combinations have taken that in hand from the start, it has provod their greatest source of strength and economy, but something also could be done among voluntary associations. Given a sufficiently intimate connection between a band of individusl traders, it is a movement that ought to make progress in this country.

It is surely to the advantage of an industry as a whole that lines which are comparatively insignificant to say an individual firm "A," and may interrupt the flow of the bulk of trade done by that firm, should be transferred to a firm "B," whose bulk business lies in those particular lines. In like case, the "B" firm might have a small line in which the "A" firm did a bulk trade, and in that way an exchange of small lines might be arranged that would be to the mutual benefit of both; each firm would thus bo enabled to give full attention to its bulk trade, freed from the hampering effect of side lines. It might be necessary during the initial period to establish a kind of trade clearing house through which these mutual arrangements might be effected, and the effort should be well worth the making.

The members of the non-ferrous metal trade have discussed among themselves the practicability of another phase of the division of industry into specialised items. The proposal is that one member should deal with copper tubes of a certain size, and another member with copper tubes of a different size, and so on, and they are now endeavouring to come to an agreement. In the textile trade there has never been any wide endeavours to specialise output, but I believe that in a tentative fashion the bleachers are beginning to tend towards centralisation on different small lines of trade.

In the textile trade of America, specialisation, favoured by the national conditions of the country and the extent of the market, has been cultivated from the start, and it is a system to which attention has been given in the glass and other trades. It may be that in the United States specialisation is encouraged by high tariffs; that the consumer is forced to be satisfied with what he can get, and that the available variety of any given article is limited because of the absence of free competition from outside. That, how. over, is a domestic concern not likely to affect this country yet awhile. In any case, from a national point of view, specialisation is highly desirable as leading to economy and expension of production, and voluntary associations in this country should give immediate attention to the subject.

Central Control.-To begin with a traism, the whole trend of industry and commerce is towards unification and centralisation. Even the war, which has altered the direction of the flow of much business, damming some industries and diverting the stream of others, has not checked this tendency to unity and to the agglomeration of interests ; amalgamations of one kind or another are reported almost weekly. The movement, indeed, is inevitable, for what 
machinery and invention have done in the past for production, this disposition of smaller bodies to consolidate in larger units is doing for administration. It has been the fashion to rail ageinst the process as having a monopolistic effect; even to-day, tho forbidding figure of a grinding trust is a favourite with the newspaper cartoonist. But with that side of the question we are not now concerned. The most severe eritic of the combine system, whethor voluntary or financial, hes to admit its effectiveness in making for economical working, and in the avoidance of waste and of overlapping. The creation of these high struetures of common interest forces to the front another phase of the problem of centralisation-that of successful management, not of combines in particular, but of any large individualistic concern. We may take as a kind of text-Centralisation for policy ; decentralisation for administration. In that phrase we find the key to successful management, and yet from the Government downwards it is rarely found to be fully carried out. For one thing, it is a policy that conflicts with the general ideas of the official mind ; for another it requires and depends upon understanding of the principles of contral control.

The art of central control is the art of getting others to persuade you to do your own way. As previously outlined, we must go for a complete example of contral control to the biggest and most successful combine the world has ever known or is likely to know-that of the armies of the Allies in the field-and we may well take from it certain instructive lessons thet may be applied to industry. In military life, we find in their most perfect form the four great qualities neces8ary to the highest state of organisation-co-operation, co-ordination, individual initiative, and unification of control. To begin at the bottom, there must bo true and unfailing co-operation between the rank and file of the individual unit - something more than the mere habit of discipline and obedience. Then the military units must be properly co-ordinated so that there shall be no waste of effort in movement or effectiveness; higher up wo must have initiative in marked degree and that individuality without which no man can aspire to direct and control. Let us see how necessary are these qualities to the proper organisation of industry-necessary not only by their presence, but in correctly regulated proportion and potency.

Co-operation in a business concern is a mainspring of efficiency, and to obtain it omployees should be assured fair treatment and just reward for services, consulted concerning difficulties, and made to feei that they are integral parts of the whole machine. Co-ordination has been well described as the arrangement of the elements of a business so that each is working to capacity and at the same time keeping every other element which is dependent upon it working to its full capacity. It also covers the inter-working between separate concerns on lines which we have already considered. It lessens waste, and at the same time assures regular and simultaneous effort directed to the common purpose-the success of the whole enterprise. Central Control itself, after all, is largely a matter either of the cultivation of the art or possession of the instinct of lesdership, or both. Leadership may be either actively dominant-not to say domineering-or passively suggestive of ideas, content merely to guide and advise the administrative staff. Successful leadership presupposes that knowledge of and consideration for the human element which nowadays is the greatest factor in production. In times past, when competition drove manufacturers to devise new mothods of lowering costs, they turned attention to improved machinery, and the economies arising from large-scale production. These have their limitations, and now the long-neglected, human factor comes into prominence as the one which, properly handled, affords the widest possibility in the lowering of eosts and the expansion of industry. Much depends upon what is intended by the phrase " properly handled." The power to impose one's will upon the subordinate administrators should rarely be necessary; the aim should be rather to implant the requisite ideas in the minds of the administrators, to be cultivated and developed by them. The desirability of this method is the greater seeing that an idea soldom reveals its full possibilities to the originating brain; it is better that it should be studied, enlarged, completed, and made "fool-proof" by others qualified by receptivity and adaptability of mind to elaborate the hints and suggestions given to them. Granted the prevision and inventiveness of the controlling head, those qualities would count for little without readiness of mind and will in the ranks below. Upon their efficiency depends the degree to which the central control has to implant or to impose, and when it becomes necessary for the control to impose, then the time arrives when the administration should be overhauled. How many times have we known machines or plant to be ruined in the hands of administrators who took no interest in them, and similar machines or plant successful in the hands of administrators who were really and actively interested in the work in hand.

As we have taken a simile from the armies of to-day, so we may borrow a word much in fashion lately in the sphere of high politics-self-cletermination. The efficiency of a system of central control may be measured by the degree to which it would be continued by the self-determination of the controlled, if and when possible. A central control to be wise must not be pontifical ; if the administrators have the brains to receive and develop ideas, they have also the brains to form them, and their own ideas on the subjoct of the efficiency of the control itself should not be regarded as negligible. Just as the doctrine of selfdetermination applies to politics, so it may be applied to industry, and it may be urged that all central controls should from time to time be examined with this in mind. The measure of importance to be attached to an investigation of this kind depends naturally upon the estimate previously formed of the efficiency of the administrative staff. At times, it might be necessary to create a central control against the desire of the controlled, but, in the main, and after the staff has established its value to the concern, its views on this point should be well worth consideration. By central control on these lines, it is submitted 
that individuality, so essential to national efficiency, can not only be maintained, but even expanded with grest benefit to the industries of the Empire, and can be coupled with the advantage of co-operation.

\section{Discussion.}

The Chalrman soid the problems of efficient and economical production were nęver more vital. To every combination which appeared to offer any solution to those problems they would be wise to give careful and very serious consideration. There was one very important thing which they might get by voluntary means. and that was the establishment of something like a regular costing system. Some manufacturers in Huddersfield district had already achieved some thing in this direction. So far as his own trade was concerned, he saw no reason why somothing effective should not be accomplished.

Mr. D. R. H. Williams (Huddersfield) said he did not know whether he was asking too much, but he thought it would be very helpful if Mr. Armitage could state briefly the steps which should be taken to get together in an industry like their own. Perhaps $\mathrm{Mr}$. Armitage could give them particulars as to the formation of the Bradford Dyers' Association. and the methods on which it is run.

The Lertorer replied that what he had said applied more to the Dyere' Federation than to the Bradford Dyers' Association. The Federation of Oyers included over 90 per cent of all the dyers in Lancashire. and the B.D.A. only formed perhaps one-third of that number. They were arranging for the exchange of statiatical information with their own competitors in the trade in Lancashire, and for the builcling up of a costs bais on the experiences of thoir own members by means of an accountant who was going around ccllecting such informntion. He could not 20 into the whole question as to how to build up a trade association which was likely to be suncessful but $h$ : wnuld say thio : Make up your minds that you are going to do nothing except get to know one another more intimately for the first six months, for all that you are likely to do in that period will probably be quite wrong. Do not think that you have got the world at your feet and you can kick it where you like. The Federation of Dyers, when it was first formed, thought they were so strong that they could control the trade. They made so many mistakes in the first six months that it took them the best part of two years to get over it.

Replying to a further question, the Lecturer said he believed that the more general information could be exchanged without in any way prying into methods of production. He did not believe it was posible, except in a financial combination, to exchange detailed methods of production, but he did believe that by porsonal intercourse they would gradually raise the level of the whole trade. In the early days, especially with mutual associations, when they met one another they were inclined to believe that the only man who told thom the truth was the customer. Nowadays it was not the customer, but their own competitor.

In reply to Mr. A. E. LEAROYD (Huddersfield), the Lecturer said the returns secured set out ordors in hand in percentages, and the number of days of work ahead, and in hand, were also indicated. An accountant went through the figures, got from them the correct total number of orders received in each separate line, and compared it with the normal which had beon agreed upon before-oither on a pre-war or some other basis. He then worked out the total porcentage which the weekly orders bore to that normal, and also showed the average number of days of work ahead in the trade as a whole in the particular line of goods. Suppoing any one turnover had fallen to 50 per cent of the normal trade and the average of th. whole trade hat fallen to 52 per cent. then there was not much to worry about. But if the average of orders for the wholo trade had remained at 100 per cent or had increased, there was a great deal to worry about. In the former case no amount of effort, either on the part of the proprietor or of his representatives, was likely to alter the percentage very much, and he was not likely to entertain the cutting of prices.

Mr. LEaroyd : You do not think that that would be just the incentive for you to go in and cut prices so $a=$ to get work and to inprove on the 50 per cent?

Mr. Armitace: You know there is not the trade there to be got, howover much you might r ut prices.

Mr. Learoyn: I am glad to hear you say it, because I had heard it said that a good many traders thought that was the time to cut prices and go in for trade. When things were bad they seemed to believe that they should cut prices and get more then their share. I am personally glad of your opinion.

The Lecrurer stated, further, that it was very difficult to arrange that one firm should make a certain kincl of goods and another f.rm shou'd manufacture another sort, unlese the firms were financially combincd. Still, in the non-ferrous melal trade. the makers of copper tubes were doing it on voluntary lines. He agroed that a central selling agency would be a national economy. If based on costing. a price association was an adrantage.

Mr. Jonn Stewart (Huddersfifld) proposed a vote of thanks to Mr. Armitage for his thought-compelling paper. Some of them, he said, in Hudderefield, had tried during a good many years, in a emall way, to arrive at a system of costs and in other ways to work together. There was no hope of any commercial success or efficiency uxcept on modern lines. This fact had been very much borne in upon them by their experience in the war. He thought he could promise that Mr. Armitage's ideas had fallen on fertile ground. and that they would bear some fruit.

Mr. Charles Kaye (Huddersfield) seconded. He said that most of those present were connected with one or other of the associations in the Huddersfeld trade, and through the course of years they had found what a very great advantage it was to exchange ideas and information with their fellow-manufacturers and competitors. They had gone some distance, in some things, on the road which Mr. Armitage had indicated. He was very much interested in one statement--that accurate co:ting prevented unduly low selling, and he thought that was quite borne out by their own experience, 
Mr. Armigage, in acknowledgment, said that national efficiency had to bo the aim of all. Capital could and would be attracted when managemont and labour were both sufficiently officient to attract capital. To-day, the problem that had got to be solved botween management and labour was that of the greatest efficiency of production that could be maintained. The gieat commercial nations in pre-war times, Great Britain, America, and Germany, each excelled in one of three qualities necessary for efficient production-quality, quantity, and methods of distribution. Great Britain excelled in quality of production, America in quantity of production, and Germany, he believed, in methods of distribution. The problem they had to solve-and it had to be solved between management and labourwas the problem of keeping that quelity of handicraft which had been bred in this country, and was still possessed, at all events in textiles, to a greater degree than in any other country, and combining with it some of the qualities of those other two countries. Nobody for long got something for nothing. It was possible that the present movement in labour was to get something for nothing. To the extent to which thet was true labour was moving against the laws of nature, and in the long run would be beaten. Labour was entitled to get the best wages that industry could afford to give in return for the best in labour. Both were subject to the laws of efficiency of production. It was up to management to endeavour to create, along with labour, the right atmosphere, so that management would be willing to give the best wages and the best conditions possible, and be entitled to have from labour the absolute best in production and the willing acceptance of all the aids that brains and machinery could give.

The Chairman was elso henrtily thanked for his servicos.

\section{LANCASHIRE SECTION.}

\author{
Meeting at Bury, 15th January, 1919.
}

Mr. Oscar S. HaLl in the Chair.

\section{SIZING.}

By R. H. Pickard, D.Se. (Lond.) F.R.S.

THE lecturer repeated a number of observations included in a previous address on the subject (seo this Journal, 1918, 9, 18).

The basis of the sizing process, he said, was very little understood, and the manufecturer had not concerned himself greatly about the investigstion of it. The relative cost of the size to that of the cloth was very small, but, since the war, had varied considerably for the kind of size employed. One reason for the neglect of investigation of the process was probably because in pre-war days the cost of the size was not a very material factor so long as tho sizer achieved the object desired.

He mointained that the great majority of the results required could be obteined with very simple mixtures. Looking at whst literature existed on the subject, one could not fail to be overwhelmed with the extraordinary number of the materials which had been used or recommended for putting into the size beck. One of the difficulties of inquiry into the subject was to ascertein that which had already beon published. In this connection, he welcomed the start which had been made in the Journal of the Textile Institute to record abstracts of textile literature. In due timo a valuable index would be available. In the matter of sizing, the only way at present was personally to consult managers and others. It did not follow, of course, that such people would communicate all they knew. In sizing, many people thought they had valuable secrets, though, as a matter of fact, the real secrets, in any case, must be very few. Most of the substances used were chosen because of the feel imparted to the cloth. The feel not only depended upon the starches used but upon the softener employed. He entered a plea for the systematic study of the softening materials, particularly tallow. Owing to the demands of other industries a number of firms had acquired experience in making fats to a given specification of hardness and melting point. The feel of the oloth was largely dependent on the fats, the approximate neutrality of which appeared to be important. The possible production of fats or waxes of almost any degreo of hardness or of melting point had opened a very wide field to the size mixer, because it should thus be possible to produce a cloth of the desired feel by varying the fat used. An added edventage was that these manufactured fats, generally spoken of as "hardened," should be without odour or colour.

Another vexed question had arisen out of the food difficulty, namely, whether the cotton manufacturer required to use wheaten flour at all. All sections of the trade were not agreed on the matter, and few manufacturers of India and China shirtings would admit that wheaten flour was unnecessary. With the exception of the gluten it contained, it was highly probable that all the common commercial starches when boiled with water gave the same substences as were present in the paste made from wheaten flour ; whilst, when flour was fermented for any length of time, to all intents and purposes the gluten was wasted.

Feel and appearance, however, were not the only considerations in sizing. Thus, from the commercial point of view, it seemed to him that sizing should be considered not only with regerd to the feel and appearance of the cloth produced, but should be studied more in detail from the point of view of the behaviour of the warp under the strain of weaving. Stoppage of the loom occurred most frequently owing to the yarn breaking close up against the fell of the cloth. The elasticity of the yarn often became exhausted at that point, and it would appear that there was greater strain on the yarn at that point than at any other. Therefore, he was inclined to inquire as to what knowledge was available as to the action of the various constituents of the size on the strength of the threads and fibres. The sizer was generally on the look-out for the increase or deorease in the 